\title{
Organization for Science
}

\author{
by our Special Correspondent
}

\begin{abstract}
Mr. Anthony Crosland, Secretary of State for Education and Science, is responsible for the administration in Britain of public support for scientific research and for the universities. The following is the outcome of an interview on January 18 -the day after the membership of the Zuckerman committee was announced in the House of Commons.
\end{abstract}

The Zuckerman committee will be able to do a useful job without disturbing the existing machinery for the administration of civil science in Britain. This is the view of Mr. Anthony Crosland, Secretary of State for Education and Science. He said that there was a "case for a committee looking at the whole field" of civil science, technology and defence.

In Mr. Crosland's view, it is probable that the committee will not wish to concern itself directly with the administration of the research councils- the ficld in which the Council for Scientific Policy under Sir Harrie Massey operates. The Minister seems to be happy with the way in which his own parish is being regulated, and clearly does not consider that there is much that outsiders would find to criticize in his own machinery for dealing with the research councils. That said, however, he is as ready as anybody to confess that it would be a great help if somebody could design rules to indicate the optimum level of spending on science and technology, as a wholo and as separate parts.

Mr. Crosland considers that the membership of the Zuckerman committee is an assurance that some hypothetical dangers will not materialize. In particular, he does not consider that the existence of a strong central committee will give the Government too much control. The "guarantees against that danger" are the men who belong to the committee, many of whom have had several years of experience as independent advisers to the Government.

The new committee, being a Cabinet committee, will function in private, and Mr. Crosland does not consider that it will be much scrutinized by the Select Committee on Science and Technology which is to be set up in the House of Commons in the months ahead. He considers that the parliamentary committee will be valuable because its field is one of "those grey areas in which you never get parliamentary debates" which provide opportunities for Members of Parliament fully to satisfy their curiosity. Mr. Crosland emphasized the educational role of the committee, especially to bogin with. It "won't start off with the research councils" and, while recognizing that it might be unfortunate if the parliamentary committee were used as a platform for sensation, he hoped that it would exorcise its prerogative to open its meetings to the public.

Given the rumours-or the hopes-there have recently been of massive public support for some schemes for European collaboration in academic science, Mr. Crosland had a moderately optimistic tale to tell. In the field of fundamental research the Government-prompted by the Council for Scientific Policy and supported by the Royal Society-has taken an initiative in O.E.C.D. to work out a system of international fellowships. The creation of what the Prime Minister has callod a European technological community is, of course, the responsibility of the Ministry of Technology and not of the Dopartment of Education and Science.

On the administration of the universities, Mr. Crosland is anxious to make it clear that the universities have in the past decade "obtained a rising share of an educational budget that has itself beon taking a rising share" of public expenditure and of the national income as well. But he

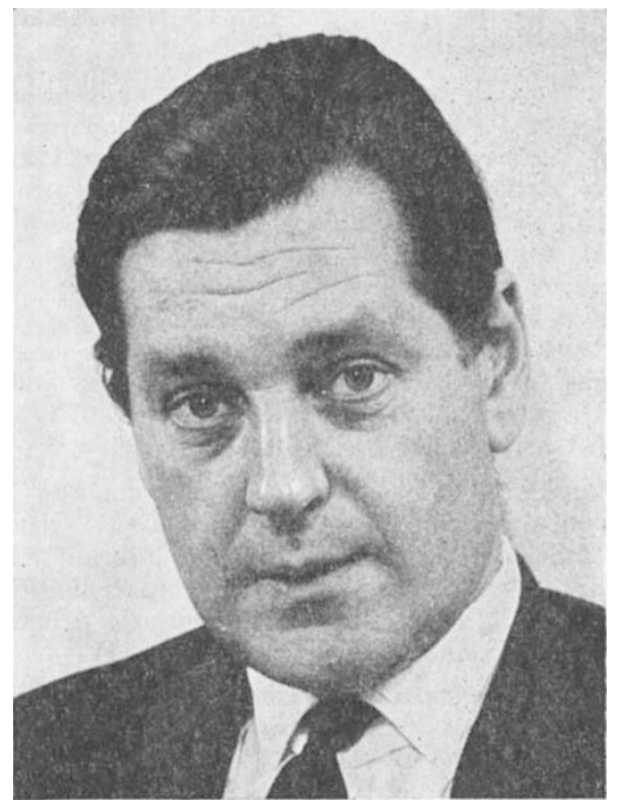

has his eyes on the cost of the operation, and is anxious to encourage current studies of such questions as the cost of educating students in universities of different kinds and sizes and the productivity of staff. He seems to be moderately cheered by the studies recently embarked on under the Committee of Vice-Chancellors and Principals of the use of plant and facilities at universities. On the pattern for rationalizing the distribution of effort of the universities, he considers it right that, taking the nation as a whole, the University Grants Committee should work through the subject panels which it has established. There may also be a case for looking at the availability of resources in higher education (in all its forms) on a regional basis as well. Several of the regional planning councils, which have strong representation from higher education, are already doing this.

The balance between the universities and the other institutions at which higher education is provided has been a bone of contention for some time, and particularly since the British Government took steps to formalize the development of the polytechnics. Mr. Crosland points out that this is not an innovation, but an attempt to make the best of a plural system which already exists. He argues that there is a "separate social demand" for a plurality of institutions of higher education. For one thing, polytechnics can provide higher education, on a part-time basis, for people already in employment. For another, they can provide degree courses oriented towards industry which more orthodox universities might be hard-pressed to provide. Mr. Crosland does not fear that the parallel development of universities and polytechnics will create an excess capacity for higher education. Rather, he seems fatalistically convinced that the rising demand for higher education will use up whatever capacity there may be created. 